Sains Peternakan Vol. 6 (2), September 2008: 31-44

ISSN 1693-8828

\title{
Formulasi Kombinasi Optimum Faktor-faktor Produksi Usaha Peternakan Sapi Perah Rakyat di Kabupaten Boyolali
}

\author{
Erlyna Wida R \\ Jurusan Sosial Ekonomi Pertanian/Agrobisnis, Fakultas Pertanian, \\ Universitas Sebelas Maret \\ Jl. Ir. Sutami 36 A, Kentingan, Surakarta
}

\begin{abstract}
The aims of this research are to 1) knowing the level of use optimum input which can yield maximum income by constraints konsentrat, bekatul, hijauan, capital, and other input, 2) Knowing change of optimal income in the change of pakan price, fresh milk price and anakan price

Basic method used in this research is descriptive. Determination of research area is purposive that is Boyolali Regency with subdistrict Musuk. And than taken one village is Sukorejo. Farmer taken as sample in this research are farmer have adult dairy cattle. Taken respondent with simple random sampling is 40 respondent farmer of dairy cattle.

Result of research indicate that maximal income which can be reached in effort ranch of scale people dairy cattle 4 tail per UT equal to Rp Rp 4.003 .592 with combination result of effort in the form of ox anakan counted 3 tail, milk counted 8.700 litre, and compost counted 15.000 $\mathrm{kg}$. Using input in the form of consentrat equal to 4.700 kilogram, bekatul counted $1.839 \mathrm{~kg}$, waste of soybean cake counted $2.053 \mathrm{~kg}$, hijauan counted $20.440 \mathrm{~kg}$. In used of resources used up and no remains.

Result of sensitivitas analysis indicate that optimal income of dairy cattle livestock are sensitive to a) increasing price of fresh milk, anakan, input and compost togetherly equal to 5\% and $10 \%$, b) decreasing price of output equal to $5 \%$ and $10 \%$ at fixed cost, c) increasing price of consentrat equal to $5-10 \%$ at the fix price of output.
\end{abstract}

Key words : optimal combination, dairy cattle, sensitivity

\section{PENDAHULUAN}

Usaha ternak sapi perah merupakan suatu usaha dengan prospek pengembangan cerah karena adanya ketersediaan tenaga kerja keluarga, pengalaman, pakan dan laju permintaan susu yang terus meningkat serta adanya dukungan perbaikan manajemen, teknologi, infrastuktur dan kebijakan dari pemerintah.
Sapi perah menjadi ikon dari Kabupaten Boyolali karena daerah ini merupakan penghasil susu terbesar di Jawa Tengah. Peternaknya terkonsentrasi di kecamatan Musuk, Selo, Ampel, Mojosongo, Cepogo, dan Boyolali. Kecamatan-kecamatan tersebut termasuk daerah dataran tinggi yang udaranya dingin karena sapi perah yang dikembangkan di Boyolali saat ini berasal dari wilayah subtropis Australia dan Selandia Baru. Hal ini dapat dilihat pada tabel berikut : 
Tabel 1. Produksi Susu di Kabupaten Boyolali Tahun 2006

\begin{tabular}{lrrr}
\hline \hline Kecamatan & $\begin{array}{c}\text { Jumlah Populasi } \\
\text { (ekor) }\end{array}$ & $\begin{array}{c}\text { Produksi Susu Ternak } \\
\text { Sapi Perah (liter/ hari) }\end{array}$ & $\begin{array}{c}\text { Produksi Susu Ternak } \\
\text { Sapi Perah (liter/ tahun) }\end{array}$ \\
\hline Musuk & 16.368 & $34.121,30$ & 12.454 .273 \\
Selo & 9.966 & $3.488,98$ & 1.273 .476 \\
Ampel & 9.639 & $4.821,48$ & 1.759 .840 \\
Mojosongo & 6.567 & $20.722,02$ & 7.563 .539 \\
Cepogo & 10.784 & $11.176,61$ & 4.079 .463 \\
Boyolali & 6.363 & $6.224,88$ & 2.272 .081 \\
\hline
\end{tabular}

Sumber data : Data BPS Kab. Boyolali Tahun 2006

Saat ini, produksi susu di Boyolali mengalami tantangan yang serius. Jumlah sapi perah serta produktivitas mengalami lonjakan naik turun dari tahun 2002 sampai tahun 2006 seperti terlihat pada tabel berikut :

Tabel 2. Populasi Sapi Perah dan Produksi Susu di Kabupaten Boyolali Tahun 2002-2006

\begin{tabular}{lrrr}
\hline \hline Tahun & $\begin{array}{c}\text { Jumlah Populasi } \\
\text { (ekor) }\end{array}$ & $\begin{array}{c}\text { Produksi Susu Ternak } \\
\text { Sapi Perah (liter) }\end{array}$ & $\begin{array}{c}\text { Produktivitas } \\
\text { (ekor/ liter/ tahun) }\end{array}$ \\
\hline 2002 & 60.205 & 30.216 .749 & 501,89 \\
2003 & 59.193 & 30.564 .853 & 516,36 \\
2004 & 60.948 & 28.921 .360 & 464,53 \\
2005 & 58.792 & 26.541 .286 & 451,44 \\
2006 & 59.687 & 29.461 .358 & 493,60 \\
\hline
\end{tabular}

Sumber : BPS Kabupaten Boyolali Tahun 2006

Oleh karena itu, penelitian ini perlu untuk dilakukan untuk bagaimana mengkombinasikan kendala - kendala input produksi dalam usaha peternakan sapi perah (yang meliputi ransum/ pakan, obat-obatan, tenaga kerja, air, serta modal) dan kombinasi output antara susu, anakan sapi dan kotorannya sehingga tercapai pendapatan yang optimal.

\section{Perumusan Masalah}

Peternakan sapi perah di Kabupaten Boyolali merupakan usaha keluarga skala kecil dan diusahakan secara tradisional. Peternakan sapi perah juga masih dicirikan oleh tingkat manajemen dan pemeliharaan yang sederhana, bahkan lokasi keberadaan ternak perah relatif baru, kondisi ternak dan praktek pemeliharaan ternak sapi sangat dibawah standart. Di samping itu juga, adanya keterbatasan-keterbatasan yang ada pada peternak dalam mengkombinasikan sumberdaya yang belum optimal seperti jumlah induk, modal, pakan, obat-obatan dan sarana produksi lainnya. Akibatnya, tingkat produksi susu masih rendah dengan rata-rata produksi 7 liter susu per hari per ekor dengan masa produktif selama 4-5 bulan sebelum birahi. Tingkat produksi susu yang rendah, mengakibatkan tingkat pendapatan yang diperolah oleh peternak juga rendah.

Pendapatan yang diperoleh oleh peternak selain dari susu sapi juga berasal dari anakan sapi. Di Boyolali muncul fenomena, dimana peternak mulai memprioritaskan sapi perah untuk diambil anakannya. Hal ini menyebabkan dalam pengelolaannya terjadi kompetisi antara usaha ternak dalam memproduksi susu dan usaha ternak dalam memproduksi anakan baik dalam penggunaan sumberdaya yang ada. 
Dengan demikian peternak akan memilih alternatif usaha peternakan dengan menggunakan sumberdaya yang mereka miliki secara optimal untuk mendapatkan pendapatan maksimal.

\section{Tujuan Penelitian}

1. Mengetahui besarnya penggunaan input optimum yang dapat menghasilkan pendapatan maksimum dengan memperhitungkan kendala-kendala pakan konsentrat, bekatul, hijauan, modal, dan sarana produksi lainnya

2. Mengetahui perubahan yang terjadi pada pendapatan optimal apabila terjadi perubahan harga pakan, harga susu segar dan harga anakan

\section{Tinjauan Teoritis}

Penelitian-penelitian mengenai sapi perah sudah banyak dilakukan ditinjau dari segi pendapatan, skala usaha, daya saing dan efisiensi. Penelitian Rachman dan Erwidodo (1999) menunjukkan bahwa pengusahaan usaha ternak sapi perah umumnya dilakukan oleh peternak rakyat dengan rata-rata skala usaha 3 ekor per peternak, dengan produktivitas berkisar antara 10-14 L/ekor/hari dan tingkat pendapatan Rp $200.000-500.000$ /ekor/tahun dengan tingkat efisiensi berkisar antara 1,1-1,8. Sedangkan penelitian yang dilakukan oleh Fajar Imawan di Kabupaten Boyolali (2005) menunjukkan bahwa peternak yang mengusahakan ternak sapi perah secara memerah susu mempunyai pendapatan yang lebih besar dari peternak yang mengusahakan ternak sapi perah yang diambil anakannya.

Dari hasil penelitian yang dilakukan Widyastuti (1997) di Kabupaten Boyolali ditemukan bahwa $80 \%$ peternak memiliki kurang dari 4 ekor, 17\% memiliki 4 - 7 ekor dan 3\% memiliki lebih dari 7 ekor. Hasil penelitian Soesilo, et.al (1999) di kabupaten
Boyolali didapatkan $72,22 \%$ peternak memiliki sapi kurang dari 5 ekor, 22,2\% memiliki sapi $5-10$ ekor dan 4,44\% memiliki lebih dari 10 ekor.

Menurut Debertin (1986) produksi merupakan suatu kegiatan atau proses mengubah masukan (input) menjadi keluaran (output). Sedangkan menurut (Yotopoulos dan Nugent, 1976) fungsi produksi adalah hubungan fisik antara variabel yang dijelaskan (Y) dan variabel yang menjelaskan (X). Variabel yang dijelaskan biasanya berupa output dan variabel yang menjelaskan biasanya berupa input. Secara matematis fungsi produksi dapat dirumuskan sebagai berikut:

Keterangan:

$$
Y=f\left(X_{1}, X_{2}, \ldots ., X_{n} ; Z_{1} \ldots Z_{n}\right)
$$

$\mathrm{Y} \quad=$ produksi (output)

$\mathrm{X}_{1} \ldots \mathrm{X}_{\mathrm{n}}=$ jumlah input produksi tidak tetap yang digunakan dalam proses produksi.

$\mathrm{Z}_{1} \ldots \mathrm{Z}_{\mathrm{n}} \quad=$ jumlah input produksi tetap yang digunakan dalam proses produksi

Pada usaha ternak sapi perah faktorfaktor yang mempengaruhi produksi antara lain terdiri dari : jumlah ternak yang dipelihara, jumlah pakan hijauan, jumlah pakan konsentrat, tenaga kerja, luas lahan yang dimiliki, keadaan ternak sapi perah (umur dan periode laktasi). Disamping itu dipengaruhi oleh keadaan social ekonomi peternak seperti umur, pendidikan, pekerjaan, pendapatan dari luar usaha ternak sapi perah.

Biaya yang digunakan untuk produksi dapat dibedakan menjadi dua macam, yaitu menjadi biaya eksplisit (secara nyata dibayarkan) dan biaya implisit (faktor produksi milik sendiri).

Pendapatan bersih usahatani (net farm income) merupakan selisih antara pendapatan kotor usahatani dan pengeluaran total usahatani. Pendapatan kotor usahatani (gross farm income) didefinisikan sebagai nilai 
produk total usahatani dalam jangka waktu tertentu, baik yang dijual maupun yang tidak dijual. Sedangkan pengeluaran total usahatani (total farm expenses) didefinisikan sebagai nilai semua masukan yang habis terpakai atau dikeluarkan di dalam produksi, tetapi tidak termasuk tenaga kerja keluarga petani (Soekartawi et al, 1986).

Tujuan optimalisasi adalah memaksimumkan keuntungan dan tercapainya efisiensi penggunaan factor produksi. Dalam kegiatan usahatani, petani dihadapkan mada masalah penentuan tingkat penggunaan sumberdaya atau input yang dapat menekan biaya serendah-rendahnya dan dapat menghasilkan keuntungan yang maksimum. Prinsip inilah yang disebut prinsip optimasi dalam usahatani (Hartono, 1989).

Dalam berusahatani, prinsip optimasi berarti mencari kombinasi penggunaan input optimal untuk berproduksi sehingga didapatkan pendapatan maksimal. Pada tingkat ini, nilai produksi dihitung dengan perkalian jumlah produk yang dihasilkan dengan harga jual produk per unit. Selisih antara nilai produksi dengan biaya yang digunakan pada tingkat penggunaan input akan menghasilkan pendapatan maksimum, maka memberikan syarat bahwa petani sebaiknya berproduksi pada tingkat yang disarankan.

\section{Model Linear Programming}

Pengertian programasi linier adalah suatu metode programasi yang variabelnya disusun dengan persamaan linier (Soekartawi,1995). Sementara Subagyo dkk (1991) menjelaskan bahwa programasi linier adalah merupakan suatu model umum yang dapat digunakan dalam pemecahan masalah pengalokasian sumber-sumber yang terbatas secara optimal.

Ada tiga komponen kuantitatif yang diperlukan dalam pemecahan dengan programasi linier, yaitu fungsi tujuan yang linier, batasan sumberdaya atau kendalakendala, dan aktivitas yang mempengaruhi fungsi tujuan dan kendala-kendala dalam bentuk hubungan linier. Menurut Subagyo dkk (1991) langkah-langkah yang ditempuh dalam perumusan masalah yang akan dianalisis dengan programasi linier adalah sebagai berikut: (1) Merumuskan tujuan, (2) Penentuan aktivitas, (3) Penentuan kendala melalui inventarisasi sumberdaya, Penentuan mutu aktivitas dan (5) Menyusun model siap diolah dengan computer.

Setiap persoalan programasi linier mempunyai dua macam analisis yaitu analisis primal dan analisis dual yang biasa disebut analisis primal-dual. Setiap masalah primal dalam programasi linier akan diikuti dengan masalah dualnya. Teori dual (kembar) dalam programasi linier sangan penting terutama untuk analisis sensitivitas. Bentuk matematis model programasi linier yang memaksimumkan fungsi tujuan yaitu:

Memaksimumkan / meminimalkan :

$Z=\sum_{j=1}^{n} C j X j$ atau memaksimumkan

meminimalkan $\mathrm{Z}=\mathrm{C}_{1} \mathrm{X}_{1}+\mathrm{C}_{2} \mathrm{X}_{2}+\ldots . .+\mathrm{C}_{\mathrm{n}} \mathrm{X}_{\mathrm{n}}$ Dengan faktor pembatas :

$\mathrm{A}_{11} \mathrm{X}_{1}+\mathrm{A}_{12} \mathrm{X}_{2}+\ldots \ldots \ldots \ldots+\mathrm{A}_{\mathrm{ij}} \mathrm{X}_{\mathrm{j}}+\ldots \ldots \ldots \ldots$ $\mathrm{A}_{1 \mathrm{n}} \mathrm{X}_{\mathrm{n}} \mathrm{b}_{1}$

$\mathrm{A}_{21} \mathrm{X}_{1}+\mathrm{A}_{22} \mathrm{X}_{2}+\ldots \ldots \ldots \ldots+\mathrm{A}_{2 \mathrm{j} X \mathrm{j}}+\ldots \ldots \ldots \ldots$ $\mathrm{A}_{2 \mathrm{n}} \mathrm{X}_{\mathrm{n}} \mathrm{b}_{2}$

$\mathrm{A}_{\mathrm{ij}} \mathrm{X}_{1}+\mathrm{A}_{\mathrm{i} 2} \mathrm{X}_{2}+\ldots \ldots \ldots \ldots+\mathrm{A}_{\mathrm{ij}} \mathrm{X}_{\mathrm{j}}+\ldots \ldots \ldots \ldots$

$A_{\text {in }} X_{n} \quad b_{i}$

$\mathrm{A}_{\mathrm{mn}} \mathrm{X}_{1}+\mathrm{A}_{\mathrm{m} 2} \mathrm{X}_{2}+\ldots \ldots \ldots+\mathrm{A}_{\mathrm{mj}} \mathrm{X}_{\mathrm{j}}+\ldots \ldots \ldots$.

$\mathrm{A}_{\mathrm{mn}} \mathrm{X}_{\mathrm{n}} \mathrm{b}_{\mathrm{m}}$

Keterangan :

$\mathrm{Z} \quad=$ nilai yang dioptimalkan

$\mathrm{Xj} \quad=$ tingkat aktivitas ke $\mathrm{j}$

$\mathrm{Cj} \quad=$ koefisien fungsi tujuan untuk aktivitas ke $\mathrm{j}$

Aij = banyaknya sumberdaya ke I yang diperlukan untuk tiap unit aktivitas ke j

$\mathrm{Bi}=$ banyaknya sumberdaya yang 
tersedia

1) $\mathrm{i}=1,2,3 \ldots \mathrm{m}$ dan $\mathrm{j}=1,2,3 \ldots \mathrm{n}$

Menurut Subagyo dkk. (1991) satusatunya jawaban yang feasible bagi permasalahan dual hanyalah yang memiliki kondisi optimal dari masalah primal. Oleh karenanya hanya permasalahan optimal dari masalah primal saja yang berhubungan dengan feasible solution masalah dualnya. Sehingga $\mathrm{Z}$ maksimum pada masalah primal adalah $y_{0}$ minimal untuk masalah dual. Apabila jawaban optimal suatu masalah primal ditentukan, maka nilai-nilai dual variabelnya (shadow price) dipakai untuk mengevaluasi apakah alokasi sumberdaya harus diubah. Shadow price $\mathrm{y}^{*}$ untuk sumberdaya ke-I menunjukkan berapa harga per unit yang bersedia dibayar untuk meningkatkan alokasi sumberdaya tersebut.

\section{Analisis Sensitivitas}

Analisis sensitivitas dilakukan setelah penyelesaian optimal tercapai (Subagyo, 1991). Selanjutnya dinyatakan bahwa pada dasarnya perubahan-perubahan yang mungkin terjadi setelah dicapainya penyelesaian optimal terdiri dari beberapa macam : 1) keterbatasan kapasitas sumber, 2) koefisienkoefisien fungsi tujuan, 3) koefisien-koefisien tehnik fungsi-fungsi batasan, 4) penambahanpenambahan variable-variabel baru, 5) penambahan batasan baru.

Secara umum perubahan-perubahan tersebut akan mengakibatkan salah satu diantaranya : 1) penyelesaian optimal tidak berubah artinya baik variable-variabel dasar maupun nilainya tidak mengalami perubahan, 2) variable-variabel dasar mengalami perubahan tetapi nilainya tidak berubah, 3) penyelesian optimal sama sekali tidak berubah.
Hipotesis yang diajukan dalam penelitian ini :
1) Diduga penggunaan input produksi usaha peternakan sapi perah rakyat belum mencapai optimum
2) Diduga perubahan harga input dan harga output akan mempengaruhi pendapatan peternak

\section{Asumsi}

Asumsi - asumsi yang dipergunakan dalam penelitian ini adalah :

1) Peternak dianggap rasional, artinya dalam mengerjakan usahanya, peternak berusaha untuk mendapatkan pendapatan maksimum

2) Tidak terjadi perubahan teknologi selama dalam penelitian

3) Semua produksi habis terjual, demikian juga input yang dibeli habis terpakai

4) Ketersediaan sumberdaya tetap dan terbatas selama dalam jangka waktu penelitian

5) Keadaan iklim, tanah dan topografi dalam jangka pendek tetap

\section{METODOLOGI}

Berdasarkan pertimbangan jumlah sapi perah tertinggi di Jawa Tengah maka penelitian ditetapkan di Kabupaten Boyolali. Pengambilan sampel kecamatan dilakukan secara purposive dengan pertimbangan kecamatan tersebut mempunyai populasi sapi perah tertinggi, yaitu kecamatan Musuk. Dari kecamatan terpilih diambil satu desa dengan pertimbangan populasi sapi perah tertinggi yaitu desa Sukorejo. Penentuan responden dilakukan secara random sampling. Kemudian diambil responden sebanyak 40 peternak.

\section{Pengolahan dan analisis data}

\section{Hipotesis}

a. Pengujian Hipotesis 1

Untuk memecahkan permasalahan bagaimana mengkombinasikan input produksi 
yang terbatas seperti pakan konsentrat, bekatul, hijauan, ampas tahu dll dengan output yaitu susu segar dan anakan sapi sehingga mencapai pendapatan yang maksimal dilakukan analisis dengan menggunakan alat analisis linear programming. Dari hasil analisis linear programming pada akhirnya diketahui aktivitas apa yang harus dilakukan dalam kegiatan suatu usaha agar dapat diperoleh pendapatan maksimal.

Apabila jawaban optimal suatu masalah linear programming (primal) telah ditentukan, maka nilai-nilai dual variabelnya (shadow price) dipakai untuk mengevaluasi apakah alokasi sumberdaya atau input harus diubah. Hasil primal menunjukkan tentang (1) berapa macam dan besarnya kegiatan yang harus dikerjakan dan nilai kegiatan itu, (2) kerugian kegiatan yang tidak disarankan dalam kegiatan optimal, apabila kegiatan itu tetap dijalankan. Hasil dual menunjukkan tentang tentang penggunaan sisa kendala yang tidak terpakai menyebutkan kendala yang merupakan pembatas utama untuk menaikkan nilai fungsi sasaran. Dual variable juga mempunyai arti nilai marjinal dari sumberdaya atau input.

b. Pengujian Hipotesis 2

Untuk mengetahui pengaruh perubahan harga input dan output terhadap pendapatan dianalisis dengan menggunakan analisis sensitivitas untuk mengatasi kelemahan model linear programming yang sifatnya deterministik (Taha, 1996). Analisis ini dilakukan untuk mengetahui kepekaan penyelesaian optimal terhadap perubahan parameter fungsi tujuan dan parameter fungsi kendala. Penyelesaian yang tidak peka terhadap perubahan parameter merupakan penyelesaian yang baik.

Dengan dilakukannya analisis sensitivitas maka perubahan harga dan perubahan ketersediaan sumberdaya dapat penelitian menunjukkan bahwa 95 persen peternak tidak memiliki sapi jantan dewasa. segera ditentukan usaha optimal yang baru sebagai akibat dari perubahan tersebut. Pada penelitian ini analisis sensitivitas dilakukan pada :

1). Kenaikan harga susu segar, anakan, kompos dan harga input secara bersamasama sebesar 5\% - 10\%

2). Penurunan harga output sebesar 5\% - 10\% pada biaya tetap

3). Kenaikan harga konsentrat sebesar 5\% $10 \%$ dengan harga output tetap

\section{HASIL DAN PEMBAHASAN}

\section{Karakteristik Usaha Peternakan Sapi Perah Rakyat}

Karakteristik usaha peternakan sapi perah rakyat ini memberikan gambaran mengenai lama usaha, permodalan dan jumlah kepemilikan sapi perah. Rata-rata lama usaha peternakan sapi perah yang dijalankan oleh peternak terbilang cukup lama sebesar 14,2 tahun dengan kisaran 2 sampai 28 tahun. Rata-rata modal awal untuk mengusahakannya sebesar Rp 3.719.000. Modal awal ini digunakan untuk membeli sapi perah, pembuatan kandang dan pengadaan sarana produksi lainnya. Sumber modal awal sebagian besar berasal dari sumber peternak sendiri sedangkan lainnya berasal dari kredit pinjaman KUD dan orang tua. Untuk pinjaman / kredit yang berasal dari KUD Musuk, tingkat suku bunga yang berlaku sebesar $1 \%$ per bulan. Cara pengembaliannya dengan potongan sebesar 1 persen setiap kali jumlah susu yang disetorkan ke KUD Musuk.

Jumlah sapi perah yang dimiliki peternak sangat bervariasi tergantung besarnya modal yang dimiliki. Sapi perah yang dipelihara meliputi sapi jantan dan betina yang terbagi berdasarkan kelompok umur yaitu dewasa ( $>24$ bulan), dara/ muda (6-24 bulan) dan pedet ( $<6$ bulan). Hasil

Peternak beranggapan bahwa sapi pejantan dalam usaha peternakan sapi perah 
merugikan karena tidak dapat menghasilkan susu padahal setiap hari sapi ini membutuhkan pakan dan tidak begitu dibutuhkan dalam perkawinan sapi. Sapi pejantan oleh peternak digunakan untuk mengerjakan lahan pertanian atau dijadikan sapi potong untuk diperjualbelikan.

Rata-rata jumlah sapi perah yang dimiliki oleh peternak sebanyak 5 ekor baik jantan, betina, dewasa maupun pedet. Sedangkan jika dilihat dari skala usahatani dengan memasukkan faktor konversi dara/ muda dan pedet dikonversikan ke sapi dewasa maka rata-rata jumlah kepemilikan sebesar 4 ekor per usahatani (UT).

Sebanyak 42,5 persen responden memiliki sapi perah antara $3-4$ ekor sedangkan sebagian kecil saja yang memiliki sapi lebih dari 4 ekor. Kebanyakan peternak memiliki sapi perah betina antara $1-2$ ekor.
Pendapatan peternak salah satunya ditentukan oleh jumlah sapi betina dewasa. Semakin banyak sapi betina dewasa yang dapat diperah maka jumlah susu segar yang dihasilkan juga semakin besar.

\section{Analisis Usaha Peternakan Sapi Perah Rakyat}

a. Biaya usaha ternak sapi perah

Biaya yang dimaksud dalam penelitian ini adalah biaya mengusahakan yaitu biaya yang dikeluarkan dalam kegiatan usaha ternak sapi perah meliputi biaya pakan, biaya obat, biaya vitamin, biaya IB, biaya penyusutan kandang dan peralatan, biaya modal kredit dan biaya air. Rata-rata biaya yang dikeluarkan oleh peternak sebagai berikut :

Tabel 3. Rata-rata Biaya Usaha Ternak Sapi Perah Per Usahatani Selama Tahun 2006 di Kecamatan Musuk Kabupaten Boyolali

\begin{tabular}{|c|c|c|c|c|}
\hline No & Uraian & Fisik $(\mathrm{Kg})$ & Biaya (Rp) & Prosentase (\%) \\
\hline 1. & Biaya pakan & & & \\
\hline & a. Konsentrat & $4.770,0$ & $4.311 .563,0$ & 51,62 \\
\hline & b. Hijauan & $1.212,5$ & $442.562,5$ & 5,30 \\
\hline & c. Bekatul & $1.839,0$ & $2.098 .750,0$ & 25,13 \\
\hline & d. Ampas Tahu & $2.053,1$ & $410.625,0$ & 4,92 \\
\hline 2. & Biaya obat-obatan & & $96.000,0$ & 1,15 \\
\hline 3. & $\begin{array}{l}\text { Biaya vitamin dan } \\
\text { mineral }\end{array}$ & & $118.500,0$ & 1,42 \\
\hline 4. & Biaya IB & & $66.875,0$ & 0,80 \\
\hline 5. & Biaya penyusutan & & $375.211,0$ & \\
\hline & kandang dan peralatan & & & 4,49 \\
\hline 6. & Biaya modal kredit & & $9.000,0$ & 0,11 \\
\hline 7. & Biaya air & & $423.750,0$ & 5,07 \\
\hline & Jumlah & & $8.352 .836,5$ & 100,00 \\
\hline
\end{tabular}

Sumber : Analisis Data Primer

Tabel 3 menunjukkan bahwa proporsi biaya terbesar dari peternakan sapi perah rakyat adalah untuk pembelian konsentrat kemudian disusul bekatul diikuti sarana produksi lainnya dalam jumlah relatif kecil. Konsentrat dan bekatul diperlukan sebagai pakan penguat dimana dalam pakan ini terkandung nutrisi yang banyak diperlukan untuk menghasilkan susu segar. Pakan konsentrat, bekatul dan ampas tahu merupakan komponen pakan yang dibeli oleh peternak sedangkan untuk hijauan, hanya 
dibeli pada musim kemarau saja karena ketersediaannya yang langka.

Pembelian air dilakukan pada musim kemarau karena sumber air milik peternak berupa sumur banyak yang mengering atau debitnya sangat sedikit. Padahal air sangat penting dalam usaha peternakan sapi perah ini. Biasanya peternak membeli dalam satu truk tangki air yang harganya bervariasi antara Rp 50.000 - Rp 70.000 tiap tangki yang berisi $5.000 \mathrm{~L}$. b. Penerimaan usaha ternak sapi perah

Proporsi penerimaan terbesar usaha ternak sapi perah rakyat berasal dari susu segar sebesar $66,79 \%$ dari total penerimaan. Di daerah penelitian, rata-rata produktivitas susu sebesar $10 \mathrm{~L} /$ ekor sapi/ hari, dimana produktivitas ini jauh lebih tinggi dibandingkan rata-rata produktivitas susu di Kabupaten Boyolali sebesar 493,60 per ekor/ liter / tahun.

Tabel 4. Rata-rata Penerimaan Usaha Ternak Sapi Perah Per Usahatani Selama Tahun 2006 di Kecamatan Musuk Kabupaten Boyolali

\begin{tabular}{|c|c|c|c|c|}
\hline No & Uraian & Fisik & Penerimaan (Rp) & Prosentase $(\%)$ \\
\hline 1. & Susu segar $(\mathrm{L})$ & 8.052 & 10.504 .810 & 66,79 \\
\hline 2. & Sapi pedet (ekor) & 3 & 4.087 .500 & 25,99 \\
\hline 3. & Pupuk kandang $(\mathrm{kg})$ & 15.147 & 1.136 .025 & 7,22 \\
\hline & Jumlah & & 15.728 .335 & 100,00 \\
\hline
\end{tabular}

Sumber : Analisis Data Primer

Rata-rata pedet yang dilahirkan dalam tahun 2006 sebanyak 3 pedet per UT. Peternak menjual sapi dara dan pedet untuk menambah keuangan dalam pengelolaan usaha peternakan ini. Jika sapi yang tidak atau belum produktif lebih besar daripada sapi produktif maka biaya yang dikeluarkan lebih besar daripada penerimaannya. Untuk menutup biaya ini maka penjualan pedet dan dara sangat membantu keuangan peternakan sapi.

c. Pendapatan usaha ternak sapi perah

Pendapatan usaha ternak sapi perah adalah pendapatan bersih yang diperhitungkan dengan mengurangi penerimaan dengan biaya mengusahakan.

Tabel 5. Rata-rata Pendapatan Usaha Ternak Sapi Perah Per Usahatani Selama tahun 2006 di Kecamatan Musuk Kabupaten Boyolali

\begin{tabular}{|c|c|c|}
\hline No & 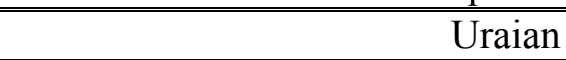 & Jumlah (Rp) \\
\hline 1. & Penerimaan & 15.728 .335 \\
\hline 2. & Biaya total & $8.352 .836,5$ \\
\hline 3. & Pendapatan & $7.375 .498,5$ \\
\hline & $\mathrm{R} / \mathrm{C}$ ratio & 1,88 \\
\hline
\end{tabular}

Sumber : Analisis Data Primer

Ditinjau dari sisi pendapatan, usaha peternakan sapi perah rakyat masih memberikan pendapatan bagi peternak. Efisiensi usaha peternakan ini dilihat dari R/C ratio sebesar 1,88 yang berarti bahwa 1 rupiah biaya yang dikeluarkan oleh peternak untuk membiayai pengelolaan usaha peternakan ini akan menghasilkan penerimaan sebesar 1,88 rupiah. Dilihat dari besarnya nilai efisiensi 
berarti efisiensi usaha peternakan sapi perah ini tergolong relatif tinggi.

\section{Optimalisasi Faktor Produksi}

Peternak sapi perah dalam usahanya berusaha untuk mendapatkan keuntungan yang sebesar-besarnya. Hanya saja pada kenyataannya peternak dihadapkan pada keterbatasan-keterbatasan pemilikan sumberdaya seperti jumlah ternak, modal, tenaga kerja dan pakan (konsentrat, bekatul, hijauan dan ampas tahu). Oleh karena itu untuk memaksimumkan pendapatan harus dilakukan pengoptimalan sumberdaya yang tersedia.

Programasi linear merupakan alat analisis yang sesuai dengan keadaan petani yang dihadapkan pada banyak keterbatasan. Dengan analisis ini dapat diperoleh kombinasi optimal dari aktivitas-aktivitas produksi dalam kondisi sumberdaya yang terbatas.

Pendapatan usaha ternak sapi perah di Kabupaten Boyolali dimaksimumkan dengan penggunaan input sesuai dengan kondisi sumber daya ekonomi rumah tangga masingmasing keluarga. Kondisi sumberdaya yang dimiliki adalah ketersediaan konsentrat, bekatul, ampas tahu dan hijauan yang masingmasing dinyatakan dalam kilogram dan IB, air, vitamin, obat-obatan yang dinyatakan dalam rupiah. Ketersediaan sumberdaya yang terbatas (binding) merupakan kendala dalam berusaha ternak. Dengan mengetahui kendalakendala yang ada akan memudahkan peternak dalam upaya meningkatkan pendapatan.

Berdasarkan hasil analisis diperoleh model fungsi tujuan dengan memaksimalkan output dengan bentuk fungsi matematisnya adalah sebagai berikut :

Maximize pendapatan $\mathrm{Z}=1.500 .000$ anakan $+1.307 \mathrm{susu}+75$ kompos

Kendala:

Konsentrat $=2.000$ anakan +2.000 susu +770 kompos $=0$

Bekatul $=1.000$ anakan $+800 \mathrm{susu}+39$ kompos $\quad=0$

Hijauan $=10.000$ anakan $+10.000 \mathrm{susu}+440$ kompos $\quad=0$

Ampas tahu $=1.000$ anakan $+1.000 \mathrm{susu}+53$ kompos $=0$

Modal $=6.000 .000$ anakan $+5.000 .000 \mathrm{susu}+168.625$ kompos $=0$

Penjualan $=-4.500 .000$ anakan $-11.370 .000 \mathrm{susu}-1.125 .000$ kompos $=0$

Tabel 6. Optimasi Penggunaan Sumberdaya dalam Usaha Peternakan Sapi Perah Rakyat

\begin{tabular}{clccccc}
\hline \multicolumn{2}{c}{ Variabel } & $\begin{array}{c}\text { Optimal } \\
\text { value }\end{array}$ & $\begin{array}{c}\text { Reduced } \\
\text { cost }\end{array}$ & $\begin{array}{c}\text { Original } \\
\text { value }\end{array}$ & $\begin{array}{c}\text { Lower } \\
\text { bound }\end{array}$ & $\begin{array}{c}\text { Upper } \\
\text { bound }\end{array}$ \\
\hline \multirow{2}{*}{ Pembelian } & Anakan & 2.000 & 0 & 2.000 & 0 & 0 \\
Konsentrat & Susu & 2.000 & 0 & 2.000 & 0 & 0 \\
& Kompos & 770 & 0 & 700 & infinity & 0 \\
& Anakan & 1.000 & 0 & 1.000 & 0 & 0 \\
Bekatul & Susu & 800 & 0 & 800 & infinity & 0 \\
& Kompos & 39 & 0 & 39 & infinity & 0 \\
& Anakan & $1.000,39$ & 0 & 1.000 & 0 & 0,0039 \\
Hijauan tahu & Susu & 1.000 & 0 & 1.000 & infinity & 0 \\
& Kompos & 53 & 0 & 53 & infinity & 0 \\
& Anakan & 10.000 & 0 & 10.000 & infinity & 0 \\
& Susu & 10.000 & 0 & 10.000 & infinity & 0 \\
& Kompos & 440 & 0 & 440 & infinity & 0 \\
\hline
\end{tabular}

Sumber Data : Analisis Data Primer 
Tabel 6 menunjukkan bahwa jumlah total konsentrat yang ada sebesar 4.700 kilogram digunakan untuk anakan sebesar $2.000 \mathrm{~kg}$, produksi susu sebesar $2.000 \mathrm{~kg}$ dan untuk kompos sebesar 770 . Selanjutnya total sumberdaya bekatul tersedia sebanyak 1.839 $\mathrm{kg}$ dengan alokasi untuk anakan sebesar 1.000 $\mathrm{kg}$, produksi susu sebesar $800 \mathrm{~kg}$ dan sisanya sebesar 39 digunakan untuk produksi kotoran. Selanjutnya, alokasi ampas tahu yang digunakan peternak selama setahun sebesar $2.053 \mathrm{~kg}$ dengan alokasi untuk anakan sebesar $1.000 \mathrm{~kg}$, susu sebesar $1.000 \mathrm{~kg}$ dan kompos sebesar 53 kilogram. Dalam penggunaannya sumberdaya tersebut habis terpakai dan tidak ada sisa. Malahan sumberdaya tersebut tergolong langka karena masih ada kekurangan sebesar 0,39 kg. Hijauan didapatkan oleh peternak dengan harga 95,88 per kilogram dengan jumlah penggunaan setahun sebanyak $20.440 \mathrm{~kg}$. Alokasi untuk anakan sebanyak $10.000 \mathrm{~kg}, 10.000 \mathrm{~kg}$ untuk susu dan 440 untuk kompos. Sumber daya tersebut sudah habis terpakai dan tidak ada sisa.

Dalam proses produksi anakan sapi, susu dan kompos selain membutuhkan pakan juga membutuhkan IB, vitamin, obat dan air.
Perhitungan untuk biaya-biaya tersebut dimasukkan dalam pengeluaran untuk modal dengan alokasi untuk inseminasi, vitamin, obat dan air masing-masing sebesar Rp 66.875, Rp 118.500, Rp 96.000 dan $\mathrm{Rp}$ 423.750. Dalam analisis ini modal dikeluarkan dari model karena untuk menghindari double accounting. Sedangkan penjualan juga dikeluarkan dari model karena penjualan bukan merupakan sumberdaya tetapi merupakan hasil dari aktivitas.

Hasil analisis ini menunjukkan bahwa penggunaan sumberdaya di tingkat peternak sudah optimal. Hal ini berbeda dengan hipotesis yang diajukan yaitu diduga penggunaan input produksi usaha peternakan sapi perah rakyat belum mencapai optimum. Kondisi ini terjadi dimungkinkan peternakan sapi perah rakyat merupakan way of life dan sudah lama menekuni bidang ini sehingga peternak sudah berpengalaman dalam mengelola usaha peternakannya untuk mengoptimalkan sumberdaya yang dimiliki.

Untuk mengetahui pengaruh variable kendala pada pendapatan peternak, dapat dilihat dari hasil analisis dual value (Toha, 1996). Hasil analisis dual value disajikan pada Tabel 7.

Tabel 7. Dual Value pada Kondisi Optimal Usaha Ternak Sapi Perah Rakyat

\begin{tabular}{|c|c|c|}
\hline Constrain & Dual value & Slack/surplus \\
\hline Konsentrat & 1.220 & 0 \\
\hline Bekatul & 0 & 0 \\
\hline Ampas Tahu & 1.300 & 0 \\
\hline Hijauan & 1.025 & 0 \\
\hline
\end{tabular}

Sumber: hasil analisis

Tabel 7 menunjukkan bahwa konsentrat merupakan bahan langka karena semua yang ada terserap dan nilai dual value sebesar 1.220 artinya satu kilogram penambahan konsentrat akan meningkatkan pendapatan sebesar $\mathrm{Rp}$ 1.220. Penambahan ampas tahu sebesar satu kilogram akan meningkatkan pendapatan sebesar Rp. 1.300 dan begitu juga hijauan, panambahannya akan meningkatkan pendapatan sebesar $\mathrm{Rp}$ 1.025. Sedang dual value bekatul sama dengan nol berarti penambahan bekatul tidak menambah pendapatan.

Slack / surplus sama dengan nol artinya tidak ada sisa dalam penggunaan sumberdaya. Hal ini berarti sumberdaya yang ada terpakai/ terserap seluruhnya dalam proses produksi. 


\section{Pola usaha ternak yang optimal}

Pola usaha ternak yang ada di Kabupaten Boyolali adalah usaha sapi anakan, susu sapi dan kompos sebagai limbah dari usaha ternak tersebut. Rata-rata jumlah sapi perah yang dimiliki oleh peternak sebanyak 5 ekor baik jantan, betina, dewasa maupun pedet. Sedangkan jika dilihat dari skala usahatani dengan memasukkan faktor konversi dara/ muda dan pedet dikonversikan ke sapi dewasa maka rata-rata jumlah kepemilikan sebesar 4 ekor per usahatani (UT).

Hasil analisis linear programming menunjukkan kombinasi hasil usaha ternak sapi perah yang dapat memberikan pendapatan optimal bagi peternak sebagai berikut:

Tabel 8. Produksi optimal untuk masing-masing usaha ternak

\begin{tabular}{lcc}
\hline \multicolumn{1}{c}{ Produksi } & Rata-rata produksi actual & Produksi optimal \\
\hline Anakan (ekor) & 3 & 3 \\
Susu (liter) & 8.700 & 8.700 \\
Kompos (kg) & 14.500 & 15.000 \\
\hline
\end{tabular}

Sumber: Hasil analisis

Berdasarkan hasil analisis yang disajikan pada Tabel 8 diketahui bahwa pendapatan optimal per usahatani per tahun dari usaha ternak sapi perah adalah sebesar Rp 4.003.592 dengan kombinasi hasil usaha berupa anakan sapi sebanyak 3 ekor, susu sebanyak 8.700 liter dan kompos/kotoran sebanyak $15.000 \mathrm{~kg}$. Hal ini berarti untuk mendapatkan pendapatan optimal, peternak sebaiknya mengatur perkawinan sehingga diperoleh anakan setiap tahunnya sebanyak 3 ekor per UT. Sedangkan untuk produksi susu sebaiknya tetap dipertahankan sebesar 8.700 liter per tahun karena jumlah ini sudah merupakan jumlah optimal. Untuk mendapatkan pendapatan optimal, sebaiknya jumlah kompos sebagai hasil sampingan juga ditingkatkan sebesar $500 \quad \mathrm{~kg}$ dengan memperbanyak pakan hijauan.

\section{Analisis Sensitivitas}

1). Kenaikan harga output dan input $5 \%$ dan $10 \%$

Perubahan harga output dan input dapat mengakibatkan perubahan pendapatan karena pendapatan dihitung dari pengurangan penerimaan yang merupakan hasil kali dari jumlah output dengan harganya dan biaya yang merupakan hasil kali dari jumlah input dengan harganya.

Tabel 9. Kenaikan Harga Output 5\% Dan 10\%

\begin{tabular}{|c|c|c|c|c|c|c|c|}
\hline \multirow{2}{*}{$\begin{array}{l}\text { Jenis } \\
\text { Produksi }\end{array}$} & \multirow[b]{2}{*}{ Produksi } & \multirow{2}{*}{$\begin{array}{l}\text { Harga } \\
(\mathrm{Rp})\end{array}$} & \multicolumn{2}{|c|}{ Kenaikan harga (Rp) } & \multicolumn{3}{|c|}{ Penerimaan (Rp) } \\
\hline & & & $5 \%$ & $10 \%$ & Normal & naik 5\% & naik $10 \%$ \\
\hline $\begin{array}{l}\text { Anakan } \\
\text { (ekor) }\end{array}$ & 3 & 1.500 .000 & 1.575 .000 & 1.732 .500 & 4.500 .000 & 4.725 .000 & 5.197 .500 \\
\hline Susu (L) & 8.700 & 1.307 & 1.372 & 1.510 & 11.370 .900 & 11.939 .445 & 13.133 .390 \\
\hline Kotoran $(\mathrm{kg})$ & 15.000 & 75 & 79 & 87 & 1.125 .000 & 1.181 .250 & 1.299 .375 \\
\hline Total & & & & & 16.995 .900 & 17.845 .695 & 19.630 .265 \\
\hline
\end{tabular}

Sumber data : hasil analisis 
Tabel 10. Kenaikan Harga Input 5\% Dan 10\%

\begin{tabular}{lrrrrrrr}
\hline \hline Jenis Biaya & Jumlah & Harga $(\mathrm{Rp})$ & \multicolumn{2}{c}{ Kenaikan harga $(\mathrm{Rp})$} & \multicolumn{3}{c}{ Biaya (Rp) } \\
\cline { 3 - 8 } & & & \multicolumn{1}{c}{$5 \%$} & \multicolumn{1}{c}{$10 \%$} & Normal & \multicolumn{1}{c}{ naik 5\% } & naik 10\% \\
\hline Sapi Induk (ekor) & 1 & 4.500 .000 & 4.725 .000 & 4.950 .000 & 4.500 .000 & 4.725 .000 & 4.725 .000 \\
Konsentrat (kg) & 4.770 & 905 & 950 & 1.045 & 4.316 .850 & 4.532 .692 & 4.985 .962 \\
Bekatul (kg) & 1.839 & 837 & 879 & 967 & 1.539 .243 & 1.616 .206 & 1.777 .826 \\
Ampas tahu (kg) & 2.053 & 155 & 163 & 179 & 318.215 & 334.125 & 367.538 \\
Hijauan (kg) & 24.400 & 95 & 99.75 & 109.725 & 2.318 .000 & 2.433 .900 & 2.677 .290 \\
\hline Total & & & & & 12.992 .308 & 13.641 .923 & 14.533 .616 \\
\hline
\end{tabular}

Sumber data : hasil analisis

Tabel 11. Perubahan Pendapatan Akibat Kenaikan Penerimaan Dan Biaya Sebesar 5\% Dan 10\%

\begin{tabular}{lrrr}
\hline \multicolumn{1}{c}{ Komponen } & Normal & Naik 5\% & \multicolumn{1}{c}{ Naik 10\% } \\
\hline Peneriman (Rp) & 16.995 .900 & 17.845 .695 & 19.630 .265 \\
Biaya (Rp) & 12.992 .308 & 13.641 .923 & 14.533 .616 \\
Pendapatan (Rp) & 4.003 .592 & 4.853 .387 & 6.637 .957 \\
\hline
\end{tabular}

Sumber data : hasil analisis

Dari ke tiga tabel di atas dapat disimpulkan bahwa kenaikan harga anakan, susu, dan kotoran sebesar 5\% dan $10 \%$ menyebabkan kenaikan penerimaan menjadi Rp17.845.695 dan Rp 19.630.265. Sedangkan kenaikan masing-masing harga input sebesar 5\% dan 10\% menyebabkan biaya meningkat menjadi Rp 13.641.923 dan Rp 14.533.616. Kondisi ini menghasilkan pendapatan sebesar $\mathrm{Rp}$ 4.853.387 dan Rp 6.637.957. Hal ini menunjukkan bahwa perubahan harga output dan input secara bersama-sama sebesar $5 \%$ dan $10 \%$ mengakibatkan pendapatan naik dan lebih besar daripada kondisi normal (pendapatan optimal). Ini berarti kenaikan harga input 5\% dan $10 \%$ tetapi diikuti harga output yang sebanding yaitu $5 \%$ dan $10 \%$ tetap menguntungkan bagi peternak.

2). Perubahan pendapatan akibat penurunan harga output sebesar 5\% - 10\% pada biaya tetap

Tabel 12. Perubahan Pendapatan Akibat Penurunan Harga Output Sebesar 5\% Dan 10\% Pada Biaya Tetap

\begin{tabular}{lrrr}
\hline \multicolumn{1}{c}{ Komponen } & Normal & Turun 5\% & \multicolumn{1}{c}{ Turun10\% } \\
\hline Peneriman (Rp) & 16.995 .900 & 16.146 .105 & 15.296 .310 \\
Biaya (Rp) & 12.992 .308 & 12.992 .308 & 12.992 .308 \\
Pendapatan (Rp) & 4.003 .592 & 3.153 .797 & 2.304 .002 \\
\hline
\end{tabular}

Sumber data : hasil analisis

Tabel 12 menunjukkan bahwa penurunan harga output sebesar 5\% dan $10 \%$ mengakibatkan penurunan pendapatan dibawah pendapatan optimal. Penurunan harga output sebesar $10 \%$ akan menurunkan pendapatan peternak sebesar kurang lebih $40 \%$ dari pendapatan optimal.
3). Perubahan harga konsentrat dengan penurunan atau kenaikan sebesar 5\% $10 \%$ dengan harga output tetap

Konsentrat merupakan pakan ternak yang sangat penting dalam usaha ternak sapi perah karena sangat berpengaruh terhadap 
produksi susu yang akhirnya akan berpengaruh pada pendapatan usaha ternak sapi perah. Perubahan biaya dan pendapatan sebagai akibat kenaikan dan penurunan harga konsentrat disajikan pada Tabel 13 - Tabel 14.

Tabel 13. Perubahan Biaya Akibat Kenaikan Harga Konsentrat Sebesar 5\% - 10\%

\begin{tabular}{|c|c|c|c|c|c|}
\hline \multirow[t]{2}{*}{ Jenis Biaya } & \multirow[t]{2}{*}{ Jumlah } & \multirow[t]{2}{*}{ Harga (Rp) } & \multicolumn{3}{|c|}{ Biaya (Rp) } \\
\hline & & & Normal & $\begin{array}{c}\text { Konsentrat naik } \\
5 \%\end{array}$ & $\begin{array}{c}\text { Konsentrat naik } \\
10 \%\end{array}$ \\
\hline $\begin{array}{l}\text { Sapi Induk } \\
\text { (ekor) }\end{array}$ & 1 & 4.500 .000 & 4.500 .000 & 4.500 .000 & 4.500 .000 \\
\hline $\begin{array}{l}\text { Konsentrat } \\
(\mathrm{kg})\end{array}$ & 4.770 & 905 & 4.316 .850 & 4.532 .693 & 4.985 .962 \\
\hline $\begin{array}{l}\text { Bekatul } \\
(\mathrm{kg})\end{array}$ & 1.839 & 837 & 1.539 .243 & 1.539 .243 & 1.539 .243 \\
\hline $\begin{array}{l}\text { Ampas tahu } \\
(\mathrm{kg}) \\
\text { Hijauan }\end{array}$ & 2.053 & 155 & 318.215 & 318.215 & 318.215 \\
\hline$(\mathrm{kg})$ & 24.400 & 95 & 2.318 .000 & 2.318 .000 & 2.318 .000 \\
\hline Total & & & 12.992 .308 & 13.208 .151 & 13.661 .420 \\
\hline
\end{tabular}

Sumber data : hasil analisis

Tabel 14. Perubahan pendapatan akibat kenaikan harga konsentrat 5\% dan 10\%

\begin{tabular}{lrrr}
\hline \multicolumn{1}{c}{ Komponen } & Normal & Naik 5\% & \multicolumn{1}{c}{ Naik 10\% } \\
\hline Peneriman (Rp) & 16.995 .900 & 16.995 .900 & 16.995 .900 \\
Biaya (Rp) & 12.992 .308 & 13.208 .151 & 13.661 .420 \\
Pendapatan (Rp) & 4.003 .592 & 3.787 .749 & 3.334 .480 \\
\hline
\end{tabular}

Sumber data : hasil analisis

Dari Tabel 13 dan 14 dapat diketahui bahwa kenaikan harga konsentrat $5 \%$ dan $10 \%$ mengakibatkan peningkatan biaya usaha ternak sapi perah menjadi Rp13.208.151 dan Rp13.661.420. Hal ini mengakibatkan penurunan pendapatan menjadi Rp3.787.750 dan Rp3.334.480. Berarti semakin tinggi harga konsentrat maka biaya semakin besar dan pendapatansemakin kecil dalam kondisi harga dan jumlah output tidak berubah. Hasil ini juga menunjukkan bahwa peningkatan harga konsentrat sebesar 5\% saja menjadikan usaha ternak sapi tidak memperoleh pendapatan yang optimal.

Hasil analisis sensitivitas menunjukkan bahwa pendapatan optimal usaha ternak sapi perah rakyat sensitive terhadap :
1). Kenaikan harga susu segar, anakan, kompos dan harga input dengan secara bersama-sama sebesar 5\% - 10\%

2). Penurunan harga output sebesar 5\% $10 \%$ pada biaya tetap

3). Kenaikan harga konsentrat sebesar 5\% $10 \%$ dengan harga output tetap.

Sehingga hipotesis yang menyatakan bahwa perubahan harga input dan harga output akan mempengaruhi pendapatan peternak adalah sesuai dengan hasil analisis.

\section{KESIMPULAN DAN SARAN}

\section{A. Kesimpulan}


1. Pendapatan maksimal yang dapat dicapai dalam usaha peternakan sapi perah rakyat skala 4 ekor per UT sebesar Rp Rp 4.003.592 dengan kombinasi hasil usaha berupa anakan sapi sebanyak 3 ekor, susu sebanyak 8.700 liter dan kompos/kotoran sebanyak $15.000 \mathrm{~kg}$. Penggunaan input berupa konsentrat sebesar 4.700 kilogram, bekatul sebanyak $1.839 \mathrm{~kg}$, ampas tahu yang digunakan peternak selama setahun sebesar $2.053 \mathrm{~kg}$, hijauan sebanyak $20.440 \mathrm{~kg}$. Dalam penggunaannya sumberdaya tersebut habis terpakai dan tidak ada sisa.

2. Hasil analisis sensitivitas menunjukkan bahwa pendapatan optimal usaha ternak sapi perah rakyat sensitive terhadap (1) Kenaikan harga susu segar, anakan, kompos dan harga input dengan secara bersama-sama sebesar 5\% $10 \%$, (2) Penurunan harga output sebesar 5\% - 10\% pada biaya tetap dan (3) Kenaikan harga konsentrat sebesar 5\% - 10\% dengan harga output tetap.

\section{B. Saran}

Pendapatan maksimal di tingkat peternak sudah tercapai dengan mengkombinasikan penggunaan input yang optimal dengan mempertahankan penggunaan sumberdaya domestik yang maksimal.

\section{DAFTAR PUSTAKA}

Anonim._ 2004. Jawa Tengah Dalam Angka. BPS Jawa Tengah. Semarang
Debertin, D.L, 1986.Agricultural Production Economic. Macmillan Publishing co. New York.

Fajar Imawan Taufiq. 2005. Analisis Usahatani Ternak Sapi Perah Terhadap peningkatan Pendapatan Petani di Kabupaten Boyolali. Skripsi. Fakultas Pertanian UNS. Surakarta.

Hartono. 1989. Optimasi Usaha Ternak Kambing PE di Kecamatan Sumber Pucung Kabupaten Malang Jawa Timur. Tesis S-2. UGM. Yogyakarta. (Tidak Dipublikasikan)

Rachman, B dan Erwidodo. 1995. Analisis Kebijakan Usaha Pengembangan Ternak Sapi Perah Domestik. Antisipasi Terhadap Kesepakatan Uruguay (GATT). Pusat Penelitian Sosial Ekonomi Pertanian. Bogor.

Soekartawi, A. Soehardjo, J.L. Dillon dan J.B. Hardaker. 1986. Ilmu Usahatani dan Penelitian Untuk Pengembangan Petani Kecil. Penerbit Universitas Indonesia. Jakarta. 1995. Teori Ekonomi Produksi. PT Raja Grafindo Persada. Jakarta.

Subagyo, P.M. Asri dan T.H. Handoko. 1991. Dasar-dasar OR. Edisi Kedua. BPFE. Yogyakarta.

Toha, A Hamdy. 1996. Riset Operasi Suatu Pengantar. Jilid 1. Edisi kelima. Terjemahan Daniel Wirajaya. Binarupa Aksara. Jakarta.

Widyastuti. 1997. Analisis Keuangan Unit Peternakan Sapi Perah di KUD Musuk Kecamatan Musuk Kabupaten Boyolali Jawa Tengah. Skripsi. Fakultas Peternakan. IPB. Bogor. 